\title{
Anthropological foundations of the didactics of history
}

\begin{abstract}
Being able to reflect on the didactics of history from a more general and cultural perspective as sociocultural anthropology offers us, has become a priority task to be able to find the theoretical foundations that support the studies that on didactics of history and social sciences, we carry out The research professors that deal with this area of knowledge, to be able to reflect on the category Cultural historical fact becomes a theoretical platform for the analysis of the racial issue, marginality, taking culture as a fundamental epicenter to perform these analyzes.
\end{abstract}

Keywords: anthropology, cultural historical fact, didactics of history
Volume 4 Issue 4 - 2019

\author{
C Roberto Fernández Naranjo \\ Department of Philosophy and History, University of Las Tunas, \\ Cuba
}

Correspondence: $C$ Roberto Fernández Naranjo, Department of Philosophy and History, University of Las Tunas, Cuba, Email bobnaranjo1975@gmail.com

Received: July 24, 2019 | Published: August 19, 2019

\section{Introduction}

The term anthropology has its origin in the Greek language; it comes from 'anthropos' which means man or human and 'logos' which is equivalent to knowledge. The etymology of the word indicates that this discipline of the Social Sciences is limited only to the study of man from the internal and external viewpoints; however, this is not so because its scope transcends society and the culture which it belongs to. From a holistic approach, anthropology is responsible for studying the origin and development of the human, and its cultural production, as well as the forms of individual behavior in society in a given space and time. Anthropology, like any scientific discipline, has a historical moment for its appearance within the set of specializations of knowledge. It is said that it appeared by the end of the eighteenth and the middle of the nineteenth centuries, with an ideological commitment to the colonial system and the belief that "the power to fully understand the other helps to submit him". This is why the first vestiges of doing anthropology (ethnography) date back to exploration and "discovery" journeys, with travel charts, navigation journals and finally chronicles. These nutritious sources provided the initial sustenance for the birth of the new area of knowledge.

As noticed, nothing closer than those same sources for the work of the historian, and which are also sources for learning history. This is where the interdisciplinary relationship between socio-cultural anthropology, history and the Didactics of History begins. Along with the above stated, several distinctive aspects of anthropological knowledge are recognized, since its applicability in diverse human spheres and activities is acknowledged, because of its holistic approach applied to the analysis of the processes that occur in society and affect daily life. As its main core concepts and its theoretical and methodological body evolved, its research method (participant observation, field work) was unveiled, which helped to put forward the categories that conform its theoretical corpus: culture, traditions, structure and symbol, among others.

\section{Socio-cultural anthropology, history and the didactics of history}

We may consider that "culture is an interpretative referent of social reality and of personal development". Its use as an interpretative referent placed in function of the formation of the new generations makes possible the deepening of the process of transmission and acquisition of culture in the school context. It also helps with the identification and analysis of the socio-cultural dynamics that take place during the formative process, in order to make critical interpretations of its impact and development. Consequently, the understanding of the diversity of educational responses from the social context is favored in order to conceive an integral formation of the students' personality. Among the authors who approach the category of culture from the anthropological perspective are: Tylor, Linton, Boas, Kroeber y Kluckhohn, Bordieu, Barbero, Canclini, Valiente, Millán y Geertz. One of the first anthropologists to define culture is Tylor who states that "Culture or civilization, in the broad ethnographic sense, is that complex whole that includes knowledge, beliefs, art, morals, law, customs and any other habits and capacities acquired by man as a member of a society".

However, the assumptions contributed by this author are limited, since they reflect only the objective components that are evident from the result of human activity. The position assumed gives more connotation to knowledge and ignores other subjective components of culture that form part of social reality such as ideas, information, experiences, emotions, heritage or values, which have a great connotation today and have been included by Linton who assumes that culture is "an organized group of ideas, habits and conditioned emotional responses". Along with this, we may state that the theoretical tradition of the study of culture is very rich. However, at present in the academic environment, its scientific projection and applicability in the social level is not always clearly seen. We defend the criterion that it constitutes a valuable interpretative referent to study and analyze the cultural particularities that are manifested in the current Cuban context. It allows understanding how the tendencies of political and economic development affect undeniably the social conduct of men.

The Didactics of History is constituted in a particular didactics, which has as object of study "the instructive, formative and educational processes of the teaching and learning of history. This object is not shared by other social sciences that also deal with subjects in the framework of society, such as psychology and sociology, or that use historical contents, but with other objectives, such as politics, philosophy and anthropology". This particular didactics for RM Álvarez de Zayas ${ }^{1}$ is the result of the didactic arrangements made to select and sequence contents graduated by periods, years, and significant events that have marked a milestone. They are taken as a starting point for the study of a concrete historical period that will later form part of the curricular 
conception of a particular educational subsystem. In spite of the clarity with which the object of study of this science and its theoretical growth has been defined in recent years, there is always a need to continue perfecting the epistemological conceptions of the didactics of history, in such a way that its theoretical enrichment finds support for practitioners and researchers to debate new interest in this area of knowledge. Additionally, it may allow seeing social representations as distinctive elements of social development, and that they find a space for reflection and understanding of the different problems that typify contemporary society from the research carried out in the didactics of history.

All this process with more successes than failures, has given significance to the didactic task of teachers and professors who make History and its didactics our sense of professional life. One particular feature is that History and other sciences share MAN (generic masculine) as part of their object of study, as outlined above. Therefore the didactics of History has dealt with how these actions of man are taught and learned in time in a dialectical relationship between pastpresent-future, from the perspective of the Integral Social History. This has meant that culture has not been taken into account as the basis for the analysis of facts, phenomena and social processes, since it has been subsumed into the interweaving of events that distinguish a historical period. Consequently, this perspective has not allowed us to dwell on the analysis of fundamental categories that help to understand the integral development of society such as: man, culture, traditions, tastes, mixed-race, indigeniety, race, ethnicity, intonation, religiosity, traditional popular culture, carrier group, among others that form part of the theoretical body of socio-cultural anthropology.

The above categories would help to enrich the content in terms of the knowledge, abilities and values that nowadays do not find a space of explicit and intentional form in the explanation that teachers make when they teach History in the different educational subsystems and in the preparation of History specialists in Pedagogical Higher Education. For this reason, we begin by recognizing the study of the historical and cultural fact as a dynamic element in the search for anthropological foundations. We see culture, in its broadest sense, as the set of material and spiritual values created by man in a concrete historical context. From this perspective it is then explained that the historical-cultural fact is constituted in the socio-cultural historical phenomena that are structured from the relations of temporality and spatiality, where complex successive and probable relations of the social actors in daily activities take place. They are the as protagonists of the history that are framed in the limits of the culture of the diverse human groups, conditioned by the influences that emerge from the contexts and circumstances of the concrete historical development.

So the community cultural event occurs as a result of the action of men in time, conditioned by the natural environment, social relations, changing contexts and circumstances created by the subjects of the participating social complex. The protagonists are all members of the community with their beliefs, creative capacities, feelings, hopes, memory and culture. By taking these reflections as premises, we are in a position to ask ourselves "Who is being educated?", and by responding we are fulfilling the anthropological function of our philosophy of education, since it would be sterile in these reflections not to take into account our learners as the driving force of development both in their instruction and in their education. Towards this direction we want to focus our attention; that is, to be able to understand man, his contradictions, frustrations, and yearnings as the starting point to better conceive the didactic process of History in the different educational subsystems. Not only that, but also to assume culture as the center and conductive thread and the product and result of the action of the man in society; it is assumed that only by making a holistic analysis of the term we will be able to understand the didactic act that today we conceive.

In this sense it is meritorious to emphasize that the teachinglearning process of History is influenced by an anthropological and sociological dimension, which distinguishes it both theoretically and practically. An example of this is that teaching at the moment requires more than ever the knowledge of the social and natural context, the available community institutions, the role of students' families, their economic-social characteristics, the heritage legacy, the predominant historical thinking and the historical memory, the environmental culture which determine the type of teaching-learning that is being promoted: developmental learning that prepares man for life. Then, based on the ideas of endoculturizing, it can be understood that the History curriculum we teach must be constructed in such a ways that it recognizes the assimilation of the values, attitudes, behaviors, ways of thinking, abilities and skills contained in our culture, since it constitutes a reflection of the way of life that we have built throughout our ethnic nation. They are in the heart of the family, before an individual arrives at school for the first time. This is why it is important to analyze families and kinship as well as their genealogical trees as social nuclei where feelings and values are forged. Besides, they distinguish people and the appropriate treatment to the cultural legacy that is exhibited today is also relevant because it constitutes a tangible and intangible part of our national identity of which Latin Americans and Cubans specifically forge our cultural heritage. Hence acculturation understood as the process through which a human group involuntarily acquires or assimilates certain values alien to its tradition, explains with solid arguments the process of shaping the Cuban as a genuine synthesis of various ethnic components, its culture and way of thinking, feelings and acting from the symbolic aspect.

That is why symbolic thought is characteristic of human beings. Although the biological constitution of the being lays the foundations for it to be possible, only through the learning of History and along with it culture, symbolic thought ceases to be a possibility to become a reality. Thanks to learning the symbolic, other biological potentialities can also be realized. "Between the fundamental plans for our life that our genes establish and the precise conduct that we actually practice, there is a complex series of significant symbols with whose direction we transform the first into the second, the fundamental plans into activity". ${ }^{2}$ This learning of the symbolic is what is called enculturation, following the reasoning of Clifford Geertz. ${ }^{2}$ Enculturation in this sense is also the process through which we constitute ourselves in cultured subjects: "To become human is to become an individual and this is achieved guided by cultural schemes by historically created systems of signification by virtue of which we form, order, sustain and direct our lives". 2

This relationship between the symbolic and the cultural constitutes a theoretical nucleus from anthropology to history and its didactics, thus the acquisition of culture (historical content) assumed as that systematized, organized and graded part for an educational subsystem through the socialization of the accumulated experience transmitted by generations (the symbolic) is the object of the teaching-learning process of History. It is conditioned by the relation between the objective and the subjective in the conception of the process and in the direction of learning. They give this a historical, social and contextualized character that linked to life in society constitutes a 
problem that makes dynamic the assimilation of the historical content. It is for this reason that through imitation, inference and teaching and learning in a general sense people know and adopt cultural patterns of meaning and conduct. We assume G Clifford's ideas when explaining that "...culture allows man to divide his experiences into manageable units (categories) and to make use of these units by means of socially learned and uniformed patterns (plans). We will argue that each culture consists of a complex set of categories and corresponding plans, which are learned in the enculturation process and which allow the people who share them to communicate with each other and meet their needs". It is therefore necessary to emphasize the social character of enculturation. Geertz explains that human survival depends less and less on the biological and more and more on the cultural. Similarly, Panamin Magnum quoted by G Clifford ${ }^{2}$ confirms the degree of dependence of humans towards learning to conserve their existence: "Man is (...) not only a social animal, but also an animal that can only become an individual if it is within a society". So there is a close relationship between two fundamental categories of socio-cultural anthropology and the didactics of history man and culture, the first represents the protagonist of history and the second the process and result of man's action in society.

\section{Issues of religiosity}

Another anthropological element is religiosity which is constituted from the existence of different cults that originated from diverse beliefs as ways men found to explain complex physical processes that occurred around them. They were the result of the low development of the productive forces (in a first moment of the development of humanity) and the impossibility of science to explain certain events (later and up to the present). This causes that a cult to different deities that conformed the different pantheons throughout the history of humanity is gradually established. Thus, different animistic conceptions appeared, like totemism and even the complex practices of contemporary religious expressions. In order to be able to explain the social development from a dialectical materialist conception it is helpful to clarify our students' conception of the world. This way they may be able to assume scientific positions in the interpretation of society and its phenomena. This is explained through the relation of the objective and the subjective in the learning of History, because the religious topic has been present in the history that is taught and learned. Nevertheless, the look at this issue has been done from very conservative positions and with certain fear since it is a taboo topic in Cuba. However, how can one explain the religious picture of contemporary Cuban society if one does not speak of its complex process of formation from the beliefs of the inhabitants of the island, with unequal cultural development, when the Europeans arrived? Before the cultural clash with the dominant culture, their almost extinct legacy was mixed with the African slaves, who brought their own religions and were incorporated into a society in which the dominant classes imposed their official religion, Catholicism. Subsequently, the spiritualism of European origin that arrived and spread provided new ingredients to the amalgam that in some nuclei was taking place and that would later be concretized in the national religious picture. Many investigations have approached this topic from the perspective of the history lesson; however, its cultural value has not been highlighted because it has only strengthened the national identity without its necessary links with the customs and traditions that mark the way to follow in the analyses that from the symbolic are made of the process.

\section{Race, racism and mixed-races}

The problems of race, racism and mixed-races are other elements of an anthropological nature and their treatment finds sustenance within the teaching-learning process of history. The racial issue in Cuba today is the object of analysis for many Cuban intellectuals, who agree that the fierce struggle currently being waged between progressive forces and the anti-black racist reaction has its origins in slavery, and the horrendous trade of human beings that the African peoples were victims. Without a doubt, racism is the most ominous inheritance of the slave trade. Cuban philosopher and anthropologist Pedro Pablo Rodríguez ${ }^{3}$ states that; "Slavery was, without a doubt, a real trauma for colonial society, the consequences of which are still felt in various aspects of Cuban life. The most scandalous thing about that institution was that it turned millions of people into slaves, that is, mere properties of other human beings, who could dispose of them to the full. It was denial of most elementary human conditions of those who suffered in their own flesh. ${ }^{3}$ It is clear that the massive influx of millions of African slaves over a hundred years, of forced immigration that far surpassed that coming from the metropolis, imposed certain stamps that have characterized the country even to the present day, especially in expressions of racism and racial discrimination. So, to be able to approach the racial problem in Cuba, from the didactics of History perspective makes it possible to reveal the need to study the cause of the racial problem from the historical knowledge system, and in this way modify the behavior contribute to preserving respect for each other without distinction of skin color.

The racial problem has been object of analysis of Cuban anthropologists. Fernando Ortiz's works showed the first studies on mixed-races in the conformation of the Cuban, as well as the economic sources on which the colony was built from, his "Cuban Counterpoint of the tobacco and the sugar", which reveals the essence of Cuba, a metaphor elaborated with wisdom and depth. The Counterpoint outlines the origins and causes of the tobacco-sugar cane economic problem, which has marked the fate of the Cuban economy and politics; it also shows a sociological imagination worthy of the postulates Wright Mill and Levis Strauss. Ortiz anticipated both of them by being a brilliant self-taught that exposes the history of these two products in a counterpoint that surpasses any previous assessment. He also delved into aspects of marginality, such as public scandals and the merit of those moments in Havana, which he shared with Miguel de Carrión, the author of "Las Impuras", one of the most controversial novels by this author, which not only reflected an era full of individual and social frustrations, but also showed the official history by revealing the negative referents that drive and at the same time slow down the social development of Cuba at the time. Another side of the problem was Nañiguismo, reflected in his work "Hampa Cubana: Los negros brujos", published in 1917, where he discovers the low strata of Cuban society never before studied. He analyzes them with some prejudice present in the young anthropologist, and follows the paths that the scientist Lombroso had marked for Criminological Anthropology. It is his first solid work, where one could already glimpse the capacity of the author and the ambitious social spectrum he wanted to cover. This work, judged by the implacable generations that succeeded him, underpins the figure of Ortiz and allows him to develop fully in the field of social sciences.

For the Cuban researcher Juan Pérez de la Riva, ${ }^{4}$ the problem is presented by giving his appreciation of the History of People without History, based on the contribution made by the million slaves and the 
one hundred thousand Chinese culies to the economic development of the Island in the 19th century that, consequently, contributed to the benefits of the Spanish metropolis. This historical fact highlights the need to study all social groups and sectors within the historiographic conceptions that take place in the twentieth and twenty-first centuries. We have revealed features of social development that are anthropological in nature, and are constituted as contents in the didactics of this science. To this are added topics already approached such as: the common man, personal, family and community history, the history of women, of trades and professions, the problem of sources, space and time as contents that go beyond the old conception of abilities, the environmental dimension, the culture of peace, and the theme of marginality. These themes have revalued the social and the cultural in a curriculum that has emphasized a positivist conception of the didactics of history.

\section{Ethnography and the didactics of history}

Ethnography is the main way of doing anthropology, since it allows for the in-depth study of an educational social unit. This makes it possible to develop three methodological acts in fieldwork, which are: recording, archiving and conserving the information extracted in fieldwork and supported by the field notebook, and then going on to epistemological acts: interpreting, explaining and arguing the main categories that emerge as a result of ethnographic work. The ethnographic method constitutes a fundamental way to treat social phenomena by their very nature, from the etymology of the word refers ethos (from the Greek ethos) which means human group united by a link of race or nationality, while graphia means description. In this sense, ethnography is interpreted as the description of groupings, that is to say, to make ethnography means to understand in detail what people do, say and think with cultural, social or any other kind of ties, who exchange visions, values and patterns, whether social, cultural, economic, among others.

In this aspect ethnography approaches the phenomenon in its natural framework, in the space where the facts occur from a subjective, qualitative and holistic perspective. The interpretative paradigm, which serves as support, emerges from knowledge derived from anthropological works or field work. In the educational level, it is developed from the reflections of Jacob, Atkinson, Delamont Hammersley who allowed identifying the variants by means of which the qualitative methodology has been used in this area of knowledge since its first decades, from different approaches. Among the most recurrent are cognitive anthropology, also called ethnoscience, which is in charge of the study of culture in mental terms. Another approach is symbolic interactionism, which assumes that individuals' experiences are mediated by their own interpretations of them. The main focus is on describing processes of symbolic interaction to understand human behavior. On the other hand, the holistic ethnographic approach seeks to discover and analyze the whole, as well as the parts of a culture or community. Aware that the modification of one of them will alter the rest, the term culture used refers to patterns of conduct, observable behaviors. The primary interest of this approach is to describe the culture, presenting it according to the vision of its participants.

Each of these approaches shows a different tendency to describe what happens in a social educational unit at the interpretative level. However, for authors such as Bronislaw Malianoswski, Paul Otkimson, Valeri Janesick, Robert E Stakel, Carlos Sandoval, Thomas J, LD Santana and Lidia Gutiérrez, cited by Gloria Pérez Serrano, ${ }^{4}$ ethnography acquires another meaning, critical ethnography, where the most significant thing about the method is precisely its surname, because it confers on it the possibility and methodology for an educational realization and development from, not only the description as essence and ethnographic purpose, but, and above all, the cultural and ideological transformation and enrichment of the people involved: teachers, students, relatives, neighbors. This enrichment may develop through critical dialogue, reflection, shared decisions, persuasion and awareness in a process defined by experiential methods and procedures such as dialectical hermeneutics, participant observation, open interviews, triangulation, among others. J Thomas states that critical ethnography is not a theory but a perspective by which a qualitative researcher can frame questions and promote action. Its purpose is the emancipation of cultural members from ideologies that are not for their benefit. Critical ethnography arises from theoretical points of critical theory. In this way, critical ethnography goes beyond a description of culture, towards action for change quoted by Gloria Pérez Serrano. ${ }^{4}$

According to the above stated, it is inferred that critical ethnography as an interactive, democratic, reflexive and dialectical method, by intervening in the natural spaces of students and social groups, object of research. It transgresses the hypothetical-deductive and experimental methods used by positivist trend research or by those who flirt with Comtian rather than Marxist approaches and with those that are more numerical than qualitative.

Critical ethnography seeks not only the description of the culture of groups of students, but the participating action of the teacherethnographer who encourages critical reflection, critical-value dialogues, meticulous analysis of the context from the different categories that emerge from the field work. This allows the interaction of the subject with reality and, therefore, the transformation of the subject from the positions and behaviors in the sociocultural context where it develops. All this methodological arsenal undoubtedly enriches the didactics of history by offering how we can explain historical phenomena and processes from experience and experience, serves as theoretical as well as methodological support. ${ }^{5-14}$

\section{Acknowledgments}

None.

\section{Conflicts of interest}

Author declares that there is no conflict of interest.

\section{References}

1. Álvarez De Zayas Rita Marina. Didactics of History and Social Sciences. Cochabamba: Bolivia; 2006.

2. Clifford Guess. Impact of the concept of Man in that of Culture. Félix Varela La Habana; 2005.

3. Rodríguez Pedro Pablo. The problem of race, raciality, racism. Thinking Against the Current. The live source. Havana; 2012.

4. Pérez Serrano Gloria. Ethnography and Critical Ethnography. Essays, Contemporary, Spain; 2006.

5. Álvarez De Zayas Rita Marina. Towards a comprehensive and contextualized curriculum. Tegucigalpa: Ed. Universitaria; 1997.

6. Álvarez De Zayas Rita Marina. History-student-society. In Education No. 95. Septiembre-diciembre, La Habana; 1998. 
7. Álvarez De Zayas Rita Marina. History to learn to live. Reality and challenge. International Congress Pedagogy ‘99, Havana; 1999.

8. Basail Alain, Daniel Álvarez. Social Anthropology. Félix Varela La Habana; 2006.

9. Basail Alain, Daniel Álvarez. Sociología de la Cultura. Félix Varela. La Habana; 2007.

10. Basail Alain, Daniel Álvarez. Antropología. Félix Varela: La Habana; 2005.

11. Bourdeau Pierre. Answers by a reflective anthropology. Páge 4 Photocopied Material; 1989.
12. Fernández Naranjo Roberto. The social phenomenon marginality in the teaching-learning process of the history of Cuba. Notes for a preliminary study. Spain; 2011.

13. Fernández Naranjo Roberto. The critical ethnographic method in the didactic approach to the social phenomenon marginality in the History discipline. Science Magazine. 2016;1(2).

14. Fernández Naranjo Roberto. Anthropologization of Historical Content in the discipline History of Cuba in Pedagogical Higher Education. Cognosis Magazine. 2017;2(4) 